\title{
Towards a lawn without grass: the journey of the imperfect lawn and its analogues
}

Article

Accepted Version

Smith, L. S. and Fellowes, M. (2013) Towards a lawn without grass: the journey of the imperfect lawn and its analogues. Studies in the History of Gardens and Designed Landscapes, 33 (3). pp. 157-169. ISSN 1943-2186 doi:

https://doi.org/10.1080/14601176.2013.799314 Available at https://centaur.reading.ac.uk/32675/

It is advisable to refer to the publisher's version if you intend to cite from the work. See Guidance on citing.

To link to this article DOI: http://dx.doi.org/10.1080/14601176.2013.799314

Publisher: Taylor \& Francis

All outputs in CentAUR are protected by Intellectual Property Rights law, including copyright law. Copyright and IPR is retained by the creators or other copyright holders. Terms and conditions for use of this material are defined in the End User Agreement.

\section{www.reading.ac.uk/centaur}

\section{CentAUR}

Central Archive at the University of Reading 
Reading's research outputs online 


\title{
Towards a lawn without grass: the journey of the imperfect lawn
}

\section{and its analogues.}

\author{
Lionel S. Smith, Mark D. E. Fellowes.
}

\begin{abstract}
:
In much of the English-speaking world, the lawn is the most common of all garden features. For arguably a millennium, it has played a significant role in the anthropogenic landscape and during that period, it has been inextricably linked with grasses. Nevertheless other plant species have accompanied the grasses and also been used in creating lawns. From medieval wildflowers to Victorian weeds, the plants that challenge the formal concept of the perfect lawn have journeyed with it but have until recently remained only small players within the dominion of grass. By the beginning of the $21^{\text {st }}$ century, with a new environmental ethos permeating the garden, the long journey of the grassy lawn and its plant companions has led to the grass monoculture being heretically rethought: by removing both the monoculture and the grass.
\end{abstract}

Keywords: Lawn, Flower lawn, Grass-free, Lawn analogues, Novum pratum.

On July $9^{\text {th }} 2000$ an article titled 'Suburban Genetics: Scientists Searching for a Perfect Lawn' appeared in the New York Times. ${ }^{1}$ It outlined research aspirations of producing genetically modified grasses that would have an improved resistance to the herbicides used to keep lawns free of weeds and that would remain green and healthy, reducing the need for fertilizers. It also highlighted additional genetic research towards creating grasses with 
greater drought tolerance to address water supply issues, a lower growth pattern to reduce the need for mowing and winter growth potential to keep lawns from becoming patchy in winter. There was even some suggestion of creating novelty grasses that might be a range of different colours or that might glow when trodden upon.

\section{The perfect lawn}

The features of grass that the geneticists are seeking to improve upon are directly related to the quest for the perfect grass lawn. To understand that quest it is necessary to identify what it is that constitutes a perfect lawn.

In the 1824 edition of Loudon's 'Encyclopaedia of Gardening', Loudon makes the comment that 'nothing should be neglected to ensure that deep green colour and velvet texture which is, or ought to be, the characteristic of the British lawn, and which is indeed the pride of our island'. 2

This is a clear indication that a perfect lawn is not just an individual object but also a composite of a number of characteristics. It is the product of an aesthetically composed veneer, and it is this aesthetic veneer and the implicit message contained within it that has come to establish the lawn as a valued aesthetic object. A neat and tidy lawn says something about its owner in the same way an unkempt lawn does. The veneer imbues the planed surface with specific aesthetic qualities. When considering colour, a rich deep green is sought in preference to browns or yellows and it should be completely weed free. Its preferred texture is smooth rather than rough and its density should be thick rather than thin. Its tonality should be a simple deep monotone rather than mottled and its tactility should be soft rather than harsh, and perhaps most significantly its defining feature height ought to be low rather

than high. ${ }^{3}$ It was the ambition to achieve, improve upon and maintain this veneer that in 1934 saw the formation of the world's first professional body dedicated to turf management - 
the Institute of Groundsmanship, ${ }^{4}$ and that has brought into being the current armoury of lawn management chemicals, tools and techniques that has so recently seen the addition of genetics.

However, the quest for a perfect lawn has not been universal. Lawns have not always been contained by proscribed aesthetic requirements. Lawns have not even always been made with grasses. It was only during the $18^{\text {th }}$ and $19^{\text {th }}$ centuries with the Victorian zeal for improvement in all things, ${ }^{5}$ that the lawn format was traditionalised through the process of characterisation and categorisation.

\section{Imperfect lawns - the beginnings}

Lawns have a long history of being imperfect and that history is widely regarded as starting in North Western Europe, in either Great Britain or Northern France.The location is highly relevant, as both Britain and northern France have a very particular prevailing type of temperate climate. Referred to as Marine West Coast in North America and Humid Oceanic in Europe, it is a distinctly moist maritime climate strongly influenced by the North Atlantic Ocean with relatively mild winters and warm humid summers. It is particularly suited to the luxuriant growth of certain grasses (Figure 1 about here). ${ }^{6}$

The etymology of the word 'lawn' can be traced back to several potential sources, launde in Old French, laund in Old English and lawnd in Middle English, each describing a pastured glade or open space within woods. All these have been offered as linguistic roots from around the $14^{\text {th }}$ century; as has the name of the French town of Laon once famous for a fine woven linen cloth referred to as 'laune lynen' or simply 'lawn'. 'However, these linguistic roots only point to potential origins of the word 'lawn' itself. The practice of maintaining what we would clearly understand to be lawns is older still. 
The gardens of English King Henry II (1113 to 1189) at Clarendon, Wiltshire were said to 'boast a wealth of lawns ${ }^{8}$ This moves the provenance of lawns to the early $12^{\text {th }}$ century, if not argueably even earlier, making the lawn nearly a thousand years old, and during the reign of Henry III in 1259 the gardens of the Palace of Westminster were recorded as being levelled with a roller and turf laid and later mown. ${ }^{9}$

Also in the $13^{\text {th }}$ century the creation of what is clearly a lawn was outlined in the chapter ' $O n$ the planting of pleasure gardens"' by Swabian nobleman Albert Magnus, Count of Bollstadt, in his thesis 'De Vegetabilibus et Plantis' ('On Vegetables and Plants') ${ }^{9}$ and Southampton Old Bowling Green is known to have had continuous lawn bowls games since 1299.

The plant constituents of these early lawns are not precisely recorded, however early descriptions of lawns appear to have been written to make it evident that they were specifically turfgrass, making them distinct from other existing types of lawn that existed at the time, such as chamomile or other low growing herbs. ${ }^{10}$ In the $13^{\text {th }}$ century Bartholemew de Glanville referred to lawns as 'pratum'; depending on context this is the Latin word for 'meadow' in English and for 'prairie' in French. ${ }^{8}$ It seems most likely a word chosen in light of their particular use, although perhaps also in part to their diverse species compositions or intensity of management.

Mediaeval tapestries and paintings of the period frequently contained garden scenes and often depicted flower-filled grassy seats and turfed ground strewn with flowers. Such meads, as they are known, have been described as 'imitations of the natural meadow, and like the natural meadow, they were starred with flowers'. ${ }^{11}$ The mediaeval flowery mead has also been dichotomously described as 'the simplest type of flower garden...wherein low-growing flowers were planted in turf lawns' and that 'medieval lawns, unlike modern ones, were 
luxuriously long, and full of flowers and herbs; they were fragrant carpets to be walked, danced, sat and lain upon'. ${ }^{12}$

It is thought difficult for a modern reader to clearly imagine walking, sitting and laying in some flowery meades, since the flowers were not exclusively low growing like those of thyme or plants of similar form, but probably as tall as they are portrayed in pictures from the period. ${ }^{13}$ These pictures show irises, lily of the valley, aquilegia, heartsease, borage, campion, poppies, hellebores, cowslips, primroses, wild strawberries, violets, daisies and daffodils. For these species to survive it would indicate that medieval meads were likely to have been mown much less frequently than the usual twice monthly mowing received by their modern lawn counterparts, since both the intensity and frequency of mowing have a strong deterministic effect on the constituents of any sward. ${ }^{14}$

A lush pictographic mead of a type known as 'millefleurs' is also sometimes referred to. ${ }^{15}$ With a literal meaning of 'thousand flowers' it is composed of both native and exotic species and early and late blooming flowers all occuring at the same time and place in a fantastic and uncontained lawnscape, like something you might find in a fantasy comic today.

Unsurprisingly fantasy millefleurs are often seen to contain mythological creatures, the most famous examples being the Unicorn Tapestries held at The Cloisters Museum in New York. ${ }^{16}$ These imagined meads are unreliable in telling us about the plants found in real meads ${ }^{17}$ but they do point to an unobtainable ideal that medieval garden keepers may have used as inspiration, a perfect flower mead to aim for; in the same way that current groundsmen and gardeners aim for the chimera that is the perfect grass lawn. ${ }^{18}$ The term 'millefleurs' has more recently been used when describing mixed perennial planting schemes that include seasonal bedding, ${ }^{19,20}$ rather than refering to any fantastic lawnscape, and Mille-Fleur-plantings are today thought of as seasonal bedding with small inflorescences, in well balanced colour combinations. $^{21}$ 
In his poem 'Legend of Good Women', contemporary of the period, Geoffrey Chaucer (13421400), notes of a medieval lawn:

'Upon the small, soft, sweet grass, That was with flowers sweet embroidered all, Of such sweetness, and such odour overall..., ${ }^{22}$

and his translation of Romaunt de la Rose indicates that medieval lawns could be substantially embellished upon.

'Ther sprang the violets al newe, And fresshe pervinke riche of hewe And floures yelowe, whyte and rede

Swich plentee grew ther never in mede ${ }^{23}$

This extract highlights that both the colours and the plants in cultivated flower lawns were different from those found in the simpler 'mede' and that species that today are frequently considered as perennial lawn weeds such as violets (Viola spp) were welcome. Periwinkle (Vinca spp) is an introduced ornamental woodland species ${ }^{24}$ and certainly not a common lawn weed in Britain, being more familiar as a cultivated low border plant. Red is a flower colour rare in the British flora ${ }^{25}$ and likely to have been either the annual scarlet pimpernel (Anagallis arvensis) or red clover (Trifolium pratense) if native species were used. The lawn species combination mentioned here by Chaucer is unusual when compared to the familiar all-grass lawn format, since colour and scent had a clear role to play. The species are also distinct from those found in taller growing meads in that they are lower growing species and are likely to have been in lawns that were mown more frequently if not particularly intensely. It seems highly probable that medieval gardeners knew how to employ different and tailored mowing regimes to produce and manage particular types of mead. A technique that is likely 
to have selectively favoured different types of forbs (broad-leaved herbs) as well as different species of grass.

The addition of plants to the lawn would have been a necessary part of creating medieval meads. Garden spaces embellished in this way are described as being 'enamelled';

enamelling being the technique of enhancing a grass sward with other plants, a technique that has been revisited in the early $21^{\text {st }}$ century in work done by Jan Woudstra and Professor James Hitchmough. ${ }^{17}$

The idealised recreation and subsequent embellishment of grassy wildflower meads may not have been entirely confined to North Western Europe. A description by Sir John Chardin in 1686 makes note that there may have been a Persian version of gardens with carpets of flowers, although its usage and form are unclear. ${ }^{26}$ The development of the mead may have also been influenced by the practice of sowing seeds from different flowers into clover lawns as recorded in some parts of the warmer and drier regions of southern Europe. ${ }^{10}$

\section{Clover}

Although not considered to be resistant to prolonged periods of drought, in the maritime climate of the UK a short internode genotype of white clover (Trifolium repens) that is commonly found in lawns, is frequently seen to persist with green leaves for longer than most lawn grasses during short periods of drought. When clover does die it leaves behind traces of nitrogen that acts as a natural fertiliser and is taken up by neighbouring plants. ${ }^{27}$

Clover's particular qualities have been exploited in the past in clover based lawns known as tapis vert that could be found during the $17^{\text {th }}$ century in France. Such lawns were composed of usually more than one legume species and included hay seed sourced from low meadow grasses. They also were recorded as specifically containing catmint (Nepeta cataria) 
in the seed mix and this suggests that scent could be a feature of this type of a lawn. ${ }^{28}$ Pure white clover lawns are unlikely to have been in use, since white clover is a short lived perennial that persists by stolons and has the habit of only retaining between forty and sixty percent coverage in a perennial sward. ${ }^{29}$ Until the mid $20^{\text {th }}$ century clover was usually included in lawn seed mixes, the greater the clover content the better the mixture was regarded. ${ }^{30}$ However from 1957 with the publication of 'A New Way to Kill Weeds in your Lawn and Garden', ${ }^{30}$ the subsequent popular use of the broadleaf herbicide 2,4-D was quick to see clover eradicated from treated lawns along with other susceptible broadleaf species. Where herbicides are not in use, very small leaved varieties commonly called 'microclovers' are often recommended as a ten percent or less constituent of lawns to help maintain good lawn colour and help exclude weeds. ${ }^{31}$

When taking into concideration current climatic trends the use of clover may, like enamelling, also be shown to have a potential relevance in the modern era. This is particularly so since there are modern parallels between the general warming of the climate that occurred in Nothern Europe (but not noticeably around the Mediterranean) during the early medieval period around $1150-1300 \mathrm{AD} .{ }^{32}$ It is only after this period during what is often referred to as 'The Little Ice Age' that the hitherto relatively common culture of warmth loving plants such as grape vines decreases substantially across the British Isles, with a commentator in 1629 noting 'The former age of our great grandfathers had all these hot herbes in much and familiar use, but this delicate age of ours...cannot...partake of the benefit of them'.33

There are ornamental forms of white clover that are available to British gardeners. In 2012, twenty-two different varieties were listed in the RHS Plant Finder. Plant breeding in the last twenty years in the UK and in both the USA and New Zealand has produced a variety of coloured leaf forms that have been shown to have garden potential. ${ }^{34}$ 


\section{Chamomile}

Another short lived perennial species that spreads by stolons and brings fragrance to a lawn is lawn chamomile (Chamamelum nobile). In the long history of being used in lawns, we might notice that Shakespeare alluded to the practice of treading chamomile to release its fragrance around 1597 in his play Henry IV (Part One, Act 2, Scene 4). Historically accessible mostly in the southern regions of England and variously on Britain's western gulf stream facing coasts, chamomile is at the northern edge of its range in the $\mathrm{UK}^{24}$ and has some tendency to lose its leaves during winter and grow poorly in very cold or seasonally waterlogged conditions. It is also thought to do better in areas with acidic soils or in soils that have the addition of an amendment such as ericaceous compost, although it is also seen growing well on limey soil.

An aromatic dwarf flowering type that requires occasional trimming once or twice a year and can be lightly mown, or a cutting propagated prostrate non-flowering clone known as 'Treneague', originally discovered in Cornwall by Dorothy Sewart in the 1930's (mysteriously either in a royal park or on her family farm), are the forms now commonly used. An ornamental double flowering form 'flore pleno' thought to have its origins in the gardens of mediaeval Christian monks is also grown and it too is propagated from cuttings. Propagation from cuttings inevitably adds both financial and time considerations to the preparation of establishing a chamomile lawn, as a result, chamomile lawns tend to be relatively small and used more as a feature and aromatic novelty than as a serious replacement for a turfgrass lawn. King George V commissioned the most famous use of chamomile in a British lawn for the gardens of Buckingham Palace, although the lawn itself is not purely composed of chamomile, rather a combination of chamomile and grasses; a mix necessary to withstand the demands made of it during garden based events. 


\section{Thyme}

With an equally long and fragrant lawn pedigree, thyme (Thymus polytriccus) has been used as a low ground cover lawn style for centuries. It was a favourite lawn alternative during the Tudor period and reappeared as an Edwardian era novelty in the early $20^{\text {th }}$ century. Today a Tudor style thyme lawn can be found between the scented garden and the moat of Sissinghurst Castle in Kent and a naturally occurring thyme lawn growing intermixed with low grasses can be seen at Ramparts Field picnic site, Icklingham, Suffolk.

Similar to chamomile, thyme lawns are generally grown for their fragrance and novelty rather than as a robust walking surface and they have the added feature of flowering over several months. The small flowers are especially favoured by bees and butterflies; for their size they are rich in nectar. ${ }^{35}$ An excess of water may cause yellowing in thyme, which prefers generally drier conditions and full sun. Heavy clay and seasonally waterlogged soils are advised against. It can be lightly mown on the highest setting with the cut spent flower heads and straggly growth removed once a year for aesthetic purposes, since thyme lawns can become undulating with small hummocks. Thyme lawns can sustain light foot traffic but will quickly wear out with regular use.

\section{Alpine lawns}

In 1966, a largely new approach came to the attention of the general gardening public with the publication of Anne Ashberry's book 'Alpine Lawns'. In it she defines an Alpine Lawn as 'a carpet of low-growing hardy plants which hug the ground, spread freely, and intermingle harmoniously', but points out that 'in nature the alpine lawn, or alpine meadow, may be an area, at high altitude, where enchanting little alpine plants grow amid lush grasses'(Figure 2

about here). ${ }^{36}$ Her book is dedicated to the use of a broad mix of low growing and spreading 
species that are not exclusively alpine, and she takes care to point out that the alpine lawn style she advocates is quite specifically without grass.

Garden based alpine lawns as outlined by Ashberry are different in several regards to common grass based lawns. There is a need for exceptionally sharp overall drainage and the obligatory rocky surface showing somewhere (Ashberry dedicates her book to the friend who gave her a 'gift of several tons of lovely tufa rock... from which grew our alpine lawn'). Also apart from occasional clipping of the chamomile, she indicates that there is little management as such, certainly no mowing since some of the included plants may be either woody species or dwarf shrubs, and mowers and rocks are not known to mix well. The plants also tend to form low hummocks and patches of different hues, representative of their species forms rather than the levelled and homogenised colour of the playing field lawn style we are more familiar with. The effect is quite different from a cut green sward of grass and there can be some horticultural challenges in maintaining alpines in the longer term in a non-alpine climate, but since the alpine lawn generally represents a selection of specifically chosen and placed plants they can be individually replaced if they do not spread or propagate themselves.

The smothering of 'weeds' through ground carpeting and therefore only a little overall maintenance requirement are a positive feature for an alpine lawn according to Ashberry. However upon falling ill and being unable to care for her own alpine lawn the current owners of Ashberry's house observe that what had once been the Alpine Lawn was now quite degraded with a much simpler grouping of Ajuga, Acaena, and 'weeds' and has inevitably required replanting. ${ }^{37}$ The Quarterly Bulletin of the Alpine Garden Society a year after the publication of Ashberry's book also notes that Alpine Lawns were quick to fall out of fashion as they became weed ridden and the alpines choked. ${ }^{38}$ 
Despite currently being out of print, Ashberry's book remains the most publicly accessible account of Alpine Lawns in Britain although it was not the first. In 1902 and aimed at a smaller specialist audience the first mention to growing alpines on 'level ground' was made, ${ }^{39}$ and in 1926 Six Hills Nursery Catalogue contains a brief article on Alpine Lawns by Clarence Elliot, the nursery's founder. ${ }^{40}$ Elliot makes a distinction between Alpine Meadows - naturalising plants in rough grass and the Alpine Lawn - where all grass is eliminated and it is formed from 'a selection of the right dwarf plants so close that they will mat together'. In this format, he notes that plants that can otherwise be quite difficult to grow 'are quite easy in the Alpine Lawn'.

The list of species Elliot identifies as suitable includes Alpine species of Anemone, Aquilegia, Arabis, Campanula, Gentian, Juniper, Lychnis, Myosotis, Primula and Viola. It is worth noting here that the primary distinction between Alpine species and similar species in the UK, apart from the obvious altitude at which many are found, is the lack of the moist maritime influence on the Alpine species in their native environments, the climatic influence so critical to the development of the grass lawn. ${ }^{41}$ Unsurprisingly most Alpine regions not only have sharp drainage but also tend to lock up winter moisture in the form of a protective blanket of snow. This is unlike milder maritime regions that experience winter rainfall and can have soil saturation throughout the winter period. Amongst other plant and site specific reasons, sitting in cold wet soil during the winter months with the development of root rot combined with the action of slugs and late frosts on exposed plants are commonly regarded to be the most frequent reasons for Alpine plants to fail in gardens. ${ }^{42,43}$

Elliot further explores the concept in a 1936 article in the Quarterly Bulletin of the Alpine Garden Society, ${ }^{44}$ yet his subsequent experiments towards a 'Flowered Lawn' with high alpines and sub-alpines in grass were apparently unsuccessful as even dwarf grasses 
eventually swamped the flowering mountain species. With one sentence, he dismisses the concept of a flower lawn by saying 'Flowered lawns seem quite unmanageable'.

\section{Yarrow}

Common Yarrow (Achillea millefolium) is an aromatic drought tolerant rhizomatous forb that has been assessed for use as a lawn alternative in Southern California. Faced with challenges of water limitation, high temperatures, drought, poor soil and volunteers not particularly keen to look after a grass lawn, a $2000 \mathrm{ft}^{2}\left(610 \mathrm{~m}^{2}\right)$ yarrow lawn was installed in a demonstration water-conserving garden at El Alisal, Los Angeles in 1987. The ground was initially traditionally prepared as if for a new grass lawn, sprinklers were installed, polythene edging added to keep the yarrow from spreading, and organic amendments added to the poor sandy soil which was subsequently fumigated to remove competitive 'weeds'.

The lawn space was sown with 'Rosy Red' yarrow in February, which flowered from mid-May until September when the woody flower stalks were cut down with a metal blade power weeder, and then a rotary lawn mower applied in a double mowing. Originally allowed to grow to 18 to 24 inches $(45$ to $61 \mathrm{~cm}$ ) in height it was not exactly a lawn in the traditional sense, more of a yarrow meadow. Management was later tailored to cutting between every six to eight weeks to allow some flowering and a meadow like aspect and later recommended for four times in the summer for a more lawn-like appearance. ${ }^{45}$

The El Alisal yarrow lawn offered a new conceptual approach to lawn composition and management. It inspired another yarrow lawn at nearby San Marcos Growers in 1991 where a smaller $650 \mathrm{ft}^{2}\left(198 \mathrm{~m}^{2}\right)$ plot was turned to lawn using a seed selection of 'White' and 'Rosy Red' yarrow and the addition of 100 randomly spaced 'Lavender Beauty' yarrow plants (Figure 3 about here). ${ }^{46}$ 
The mixed response to the yarrow lawn prompted one well-published Californian garden designer to comment: 'For designers of low-water-use gardens no problem is more difficult than finding acceptable alternatives to mowed turf. Any number of substitute ground covers or pavings may be proposed to retain the openness, simplicity, and tranquillity of lawn, but clients often protest the loss of the traditional green sward'. ${ }^{45}$ However twenty years on several well-known Californian garden designers and cities now recommend and use yarrow as a lawn substitute. ${ }^{47,48}$

\section{Selfheal}

Further north in Eugene, Oregon, in a moist maritime climate similar to that experienced in the UK, the British native species Selfheal (Prunella vulgaris) has also been used as a front lawn alternative for nearly a decade (Figure 4 about here). Its owner and creator Hugh Prichard reports mowing can be done as often or infrequently as desired; in comparison to the weekly mowing the neighbours lawns receive. In summer the lawn is awash with violetpurple blooms and is only mown once they have faded (Figure 5 about here). The lawn receives an annual top up of seeds to maintain its density and to replace the plants that have flowered themselves to exhaustion. The only drawback noted has been a tendency for selfheal to lose its leaves at temperatures not far below zero Celsius and leave a lawn space bare of foliage. $^{49}$

\section{Analogues}

Dependent on climate and local environmental conditions other single plant species have sometimes been used as lawn substitutes. These are variously suggested to include: Corsican Mint (Mentha requenii), Smooth rupturewort (Herniaria glabra), Frogfruit /Turkey Tangle (Phyla nodiflora), Strawberry clover (Trifolium fragiferum), Carpet gazania (Dymondia margaretae), Alpine water fern /Pinque (Blechnum penna-marina), Creeping peanut/Golden 
glory (Arachis glabrata), Pennyroyal (Mentha pulegium), Lawn lobelias (Pratia spp), Pearlwort /Irish moss (Sagina subulata), Lawn pennywort (Hydrocotyle sibthorpioides), Tideturf /Swampweed (Selliera ssp), Capeweed (Arctotheca calendula), Mercury Bay weed (Dichondra repens), Beach strawberry (Fragaria chiloensis), Swamp Musk (Mazus radicans), Cotula (Leptinella spp), Piri-piri burr (Acaena ssp), Sedges (Carex spp), and Mosses.

From this list, that includes a fern, a strawberry and a peanut the question arises whether a lawn substitute can actually be a lawn at all, but rather be a creative use of what are commonly thought of as particularly low growing and ground covering plants. This would equally apply to species such as chamomile and thyme that by tradition have the lawn epithet attached to them. Such species are plants being used in a manner that is simply aesthetically similar to how turf can be used, although lawns themselves have been described as "nothing but superlative examples of ground cover on a big scale ${ }^{50}$ This type of usage is a process gardeners everywhere are familiar with when working creatively with different species to achieve particular aesthetic effects in light of the local environmental conditions. Grass lawns have very specific and well-characterised aesthetic components that lawn substitutes either lack, or have in unsatisfactory measure. Substitutes have characteristics that are entirely their own. Yet sometimes those different characteristics can be thought of as being equal or even superior to grass. Perhaps ironically it has been in the most ancient of sporting uses for frequently mown fine lawn turf that the clearest sign of change in the long held and almost sacrosanct grass tradition first appeared.

In Dunedin, New Zealand in 1913, the groundsman of the Caledonian Bowls Club found that a native weed species Leptinella dioica (Cotula) had invaded the bowling lawns and attempted its removal by scarifying the lawns surface. This had the opposite effect and spread the weed. Over a number of years the weed came to dominate the lawn and during this 
time the players had noticed how the surface played a superior and faster game. ${ }^{51}$ In 1923 other clubs began adding the weed to their lawns, transforming it from a weed to the status of a desired plant - the right plant in the right place; and in 1930 The Caledonian Bowls Club became the first bowls club to replace grass entirely (Figure 6 about here) ${ }^{52,53}$ Another New Zealand native that also spreads vegetatively (Leptinella maniototo) is now also used in the creation of fast bowling lawns. ${ }^{54}$

\section{What is a lawn?}

So what defines a 'true' lawn? Is it an internal composition made up of only grass species, is it the primary use of a single species, the height of the sward, the method and frequency of cutting, its socio-economic value, or its aesthetic qualities or its usage? By the very fact that these questions can be legitimately asked and are not answered by the traditionalised definition of a lawn, suggests the line of definition has been crossed. We have moved beyond the restrictive Victorian characterisation of what a lawn should be to a novum pratum - a new lawn.

Many Britons today will be able to look out on lightly managed grass lawns that contain native plants such as daisies, buttercups and white clover; plants that survive and even thrive in the environment peculiar to the garden lawn. In 2001 such lawns were termed 'Freedom Lawns' to distinguish them from intensively managed monoculture 'Industrial Lawns' ${ }^{55}$ These lawns have largely devolved from the original grass-only turf and like their earlier medieval forebears are now sprinkled with wildflowers or weeds depending on your viewpoint. For the most part, real everyday early $21^{\text {st }}$ century lawns are multi-species in the UK today, the imperfect lawns berated by purists. Often these have come into being by default, but in an ever-increasing manner also by design.

\section{A new ethos and a new look}


At the end of the $20^{\text {th }}$ century a new ecological aesthetic began permeating gardening, positing that which looks good is that which also does not have negative ecological consequences ${ }^{56}$ but this has not been readily taken up by lawn owners, where tradition still has a firm hold. ${ }^{57}$ Yet seed houses are now offering flowering lawn seed and pre-sown flower lawn mats for easy and quick installation. The lawn by design has been made to expand beyond its traditional definition, and being by design, it has acquired some of the necessary traditional cues to care. ${ }^{58}$ The constituent species have being carefully selected for purposes other than texture and tonality; instead, motivations of colour, less intensive management, nectar sources and biodiversity have been incorporated. Similar requirements have seen the rise of floriferous urban meadows in the anthropogenic landscape,${ }^{59}$ but the defining feature of a lawn - its low disposition, and its defining management technique - regular mowing, disqualifies meadows from any location where a low cut is preferred.

Garden enthusiasts have by design been experimenting with grass varieties and forb mixtures. ${ }^{60,61}$ Work towards a construct termed the 'Ecolawn' by Professor Tom Cook at Oregon State University during the 1990's combined selected grasses with broadleaf plants, with the aim of producing an ecologically stable mixture of plants that would persist with fewer inputs than a traditional lawn. The specific aim was the reduction of mowing, irrigation and the use of fertilizers, and pesticides; aesthetics were a secondary but not unimportant criterion. ${ }^{62,63}$ There was also some tentative and inconclusive research toward breeding more aesthetically pleasing forms of grasses and common lawn dicots specifically for floral lawns in the late 1980s in New Zealand. ${ }^{64}$

This type of experimentation has led to the development of grass and forb mixtures currently available with names such as 'Flowering Lawn', 'Ecology Lawn Mix', 'Fragrant Herbal' and 'Fleur de Lawn' ${ }^{\circledast}$. A grass cultivar selected lawn planted to be well-endowed with daisies, buttercups, selfheal and other lawn tolerant dicots can be desired and 
encouraged, ${ }^{65}$ and indigenous species have been incorporated or allowed to colonise traditional turf lawns. ${ }^{66}$ These developments have led to perhaps the last big step for the lawn, where it has become its own antithesis and lost its grass entirely.

\section{Lawn heresy}

In autumn 2010 in the Biological Sciences experimental grounds of the University of Reading, Berkshire, England, a series of thirty six small grass-free lawns using ten native and ten non-native forb species were created to test the hypothesis that a grass-free lawn could be created and perennially maintained. The local topsoil was removed to a depth of $6 \mathrm{~cm}\left(2.3^{\prime \prime}\right)$ and 100 individual plug plants used in each trial lawn. The lawns were subject to three mowing regimes, the cuttings collected and weighed, the flowers counted, and the behaviour of individual species and their coverage monitored. The behaviour of these trial lawns was compared to nine grass plots of the same size that had been sourced from the university's own lightly managed freedom lawn. From the careful monitoring and analysis, it has been possible to determine that lawns can be created to be grass-free.

By using clonal perennial forbs that spread by rhizomes and stolons in addition to potentially producing seed, it has been possible to show that grass-free lawns can not only produce a complete green ground coverage in the same manner as a lightly managed lawn, but that they also produce many more flowers than a freedom lawn. They also require significantly less mowing; a feature related to the architectural response of many forb species to repeated defoliation and the repeated interruption of apical growth. By the end of the experiment in winter 2012, there had been no requirement for additional inputs and the need for mowing had been shown to be a third of that required for a grass lawn. Such lawns are not a replacement for hardwearing turf, but they show all the cues to care found in a traditional grass lawn; they are mown, designed, show human intent and on-going care and additionally 
they are full of flowers (Figure 7 about here). So much so that without the use of grasses it is arguably possible to call them de facto flowering lawns, since the components all have the potential to produce flowers. This lack of grasses has inevitably led to a return to the debate as to whether they can be termed lawns at all, but rather that they are low growing extensions of the garden border, although this seems to be predicated on the necessary presence of a border.

Surprisingly, considering the recent ecological aesthetic and a dubious trend for using native species wherever possible,${ }^{67}$ it has been this particular feature of the grass-free lawns that has caused some angst amongst lawn traditionalists. A creeping buttercup (Ranunculus repens) in a traditionally well-managed grass lawn is a weed. By contrast, a buttercup in a grass-free lawn is a chosen component of the construct and part of the overall composition of resilient and diverse species; it seems a grass-free lawn can be perceived as 'a bunch of weeds' when viewed through traditionalist eyes. Perhaps even more surprising is that when presented with the very same native species but using ornamental cultivars e.g. Ranunculus repens 'Gloria Spale' instead of familiar common forms, the perception is shifted from a bunch of weeds to something novel, pretty, and even perhaps desirable. There appears to be a subtle difference in the mind's eye between 'weeds' and unusual or 'pretty weeds' even if they are one and the same species, giving credence to the familiar adage that a weed is simply the wrong plant in the wrong place. Grasses become the weeds in a grass-free lawn.

\section{The flowering of the lawn}

The variety of potential constituent plant species has opened the door to all types of creative uses for a grass-free lawn, and for the use of many types and forms of both familiar and neglected lawn tolerant species. The experiments in Reading used over eighty-five different species drawn largely from climatically similar temperate regions of the world. Each species 
has its own niche tolerances across moisture levels, light requirements, soil and fertility gradients ensuring that at least some of the species at any one time will thrive under the prevailing environmental conditions. The single entity that is the lawn evolves to become a dynamic and aesthetically diverse multi-species sward.

It has been shown that through careful selection of lawn tolerant species and cultivars combined with a suitable mowing regime, that it is possible to include a palette of colour in both flower and leaf and to choose for biodiversity and effect, including scent. Plants used include violets, clovers, chamomile, thyme, yarrow, selfheal, lawn lobelias and Leptinella dioica. This increased flexibility of composition, floral colour and concomitant increased biodiversity has retained the conventional low growth pattern and displays the traditional requirements for care. So much so that during May of 2013 a $220 \mathrm{~m}^{2}\left(720 \mathrm{ft}^{2}\right)$ example of a seventy five species grass-free lawn was installed in Avondale Park in the London Borough of Kensington \& Chelsea, to replace a small wildflower meadow that had become difficult to maintain in good form. In the process, Avondale Park became the first public example of a grass-free flower lawn. Subsequent installations are planned for a neighbouring park and for public and private gardens elsewhere and a demonstration example of a grass-free floral lawn was exhibited in the RHS Environment section of the centenary Chelsea Flower Show in May 2013.

For almost a millennium grasses have been cut low and frequently, to provide the monochrome lawns that have gone on to feature in the gardens and parks of the world. They have added to the quality of life in urban spaces, with practical uses beyond that offered by their broad-leaved cousins. Yet their continued evolution beyond the occasional garden curiosity of other species monocultures has been stymied by the traditional requirement that they must by definition contain grass. Without grasses, the flowers of the medieval lawn can return, and the scents of the Tudors and the visual tapestry of the Alpine lawn can be 
rejuvenated in a new lawn format that builds on the past and addresses the present, all without the need for genetic intervention.

In an age that increasingly faces significantly new social, economic and environmental challenges quite different from times gone by, it has surely been timely for the lawn to be released from its traditional constricting identification with grass and been allowed to flower. 
NOTES:

1 David. Barboza, 'Suburban Genetics: Scientists Searching for a Perfect Lawn', New York Times, 9 June 2000.

2 J.C. Loudon, 'An Encyclopaedia of Gardening. Comprising the Theory and Practice of Horticulture, Floriculture, Arboriculture and Landscape Gardening; Including the Latest Improvements; a General History of Gardening in All Countries and a Statistical View of Its Present State, with Suggestions for Its Future Progress in the British Isles.', (London: Longman, Hurst, Rees, Orme, Brown \& Green., 1824), p. 821.

3 Eamonn. Slater, 'The Front Lawn as a Work of Art and Nature in the Age of Chemical Reproduction', in Annual Meeting of the American Sociological Association 2007. (New York, 2007).

4 Anon, 'Institute of Groundsmanship.', IOG, (2012)).

5 Asa. Briggs, The Age of Improvement: 1783-1867. 2nd edn (New York: Longman, 2000).

6 C.E. Hubbard, Grasses: A Guide to Their Structure, Identification, Uses and Distribution in the British Isles. (London: Penguin, 1954).

7 Ernest. Klein, A Comprehensive Etymological Dictionary of the English Language. Vol. 2 (Amsterdam, London, New York.: Elsevier., 1967).

8 T. Fort, 'The Grass Is Greener.', (London: Harper Collins, 2000), p. 23.

$9 \quad$ J. Harvey, Medieval Gardens (London: Batsford, 1981).

10 Richard Bisgrove, 'All the Best Hayloft Sweepings, and, for or against the Daisies.', Country Life, 179. 1986, pp. 1316-18, 454-456.

11 E. S. Rohde, Lawns. The Nineteenth Century and After. (New York. NY: Leonard Scott Pub. Co., 1928).

12 T. McLean, Medieval English Gardens. (London: Collins, 1982). 

Shrubs Grown in the Middle Ages with Some Account of Tudor, Elizabethan and Stuart Gardens. (New York. NY: Hacker Art Books, 1979).

14 Ari-Pekka. Huhta, 'Restorative Mowing on Semi-Natural Grasslands: Community-Level Changes and Species-Level Responses.' (PhD Thesis, University of Oulu, Finland., 2001).

15 Sylvia Landsberg, The Medieval Garden (London: British Museum Press, 1998).

16 Anon, 'The Unicorn in Captivity', in Unicorn Tapestries, ed. by Metropolitan Museum of Art (New York: Metropolitan Museum of Art, 1495-1505).

17 J. Woudstra, and J. Hitchmough, 'The Enamelled Mead: History and Practice of Exotic Perennials Grown in Grassy Swards', Landscape Research, 25 (2000), 29-47.

18 T. Steinberg, American Green: The Obsessive Quest for the Perfect Lawn (New York, NY: W.W. Norton \& Co, 2007).

19 W. Borchardt, 'Planning Strategies for Perennial Plantations, Part 1.', Deutscher Gartenbau., 25 (2006), 28-30.

20 - - , 'Planning Strategies for Perennial Plantations, Part 2. ', Deutscher Gartenbau., 27 (2006), 30-32.

21 W. Messer Kirsher, U. Fenzle, J. Heins, M, Dunnet, N. , 'Optimizing the Visual Quality and Cost Effectiveness of Perennial Plantings by Randomly Mixed Combinations - Application Approaches for Planting Design.', in Digital Landscape Architecture. (Anhalt University of Applied Sciences, 2012).

22 Geoffrey. Chaucer, 'The Legend of Good Women', (Between 1386-1388).

$23---$, 'Romaunt of the Rose', (1431).

24 Anon, 'Ecological Flora of the British Isles.', (http://www.ecoflora.co.uk 2010).

25 John. Warren, and Sally. Mackenzie, 'Why Are All Colour Combinations Not Equally Represented as Flower-Colour Polymorphisms?', New Phytologist, 51 (2001), 237-341.

26 John. Chardin, Sir John Chardin's Travels in Persia (New York: Cosimo Inc, 2011). 
27 J. J. Burdon, 'Biological Flora of the British-Isles .154. Trifolium-Repens L', Journal of Ecology, 71 (1983), 307-30.

28 J. James, The Theory and Practice of Gardening. (London: Maurice Atkins, 1712).

29 David. Patriquin, 'Establishing White Clover in Lawns.', Versicolor, (2004 \& 2012) <http://versicolor.ca/lawns/docs/clover.html>2013].

30 Reginald. Milton Carleton, New Way to Kill Weeds in Your Lawn and Garden.(Fawcett Publications. Greenwich, Conn, 1957).

31 M. Wagner, W. Henle, H. Schneider, and W. Claupein, 'Microclover - Einsatz Von Kleinblättrigem Klee Auf Rasenflächen', European Journal of Turfgrass Science 3(2010), 3-8.

32 M. D. Hughes, Was There a Medieval Warm Period? (Dordrecht: Kluwer Academic Publishers, 1994).

33 A.M. Amherst, A History of Gardening in England. 3 edn (London: John Murray, 1910).

34 Rebecca. M. Tashiro, Joseph. H. Bouton, and Wayne. A. Parrott, "Frosty Morning', 'Patchwork Quilt', 'Irish Mist', and 'Pistachio Ice Cream' Ornamental White Clover (Trifolium Repens L.) ', HortScience, 44 (2009), 1779-82

35 Livia. Persano. Oddo, Lucia. Piana, Stefan. Bogdanov, Antonio. Bentabol, Panagiota. Gotsiou, Jacob. Kerkvliet, Peter. Martin, Monique. Morlot, Alberto. Ortiz. Valbuena, Kaspar. Ruoff, and Katharine. von der Ohei, 'Botanical Species Giving Unifloral Honey in Europe', Apidologie, 35 (2004), S82-S93.

36 Anne. Ashberry, Alpine Lawns - with Some Account of the Special Use of Carpeting and Crevace Plants. (London: Hodder \& Staughton, 1966).

37 Nicola. Starkey, 'Can an Alpine Lawn Have a Place in a Contemporary Garden?' (RHS Dissertation. Harlow Carr., 2010).

38 F.H. Fisher, 'Trends in the Cultivation of Alpine Plants', Quarterly Bulletin of the Alpine Garden Society 1967, pp. 227-34. 
39 W. Robinson, Alpine Flowers for Gardens : Rock, Wall, Marsh Plants, and Mountain Shrubs (London: John Murray, 1903).

40 Clarence Elliot, 'The Alpine Lawn', in Six Hills Nursery Catalogue, 1926), pp. 8-10.

41 S. H. Thompson, 'Part I. Chapter I. Sub-Alpine Plants - and Where They Grow: A Comparison with the Flora of Britain', in Sub-Alpine Plants or Flowers of the Swiss Woods and MeadowsG Routledge \& Sons Ltd, 1912).

42 Christian. Körner, Alpine Plant Life: Functional Plant Ecology of High Mountain Ecosystems (Berlin, Heidelberg, New York: Springer, 1999).

43 E.G. Good, and D. Millward, Alpine Plants: Ecology for Gardeners. (London: Batsford, 2007).

44 Clarence Elliot, 'The Alpine Lawn', Quarterly Bulletin of the Alpine Garden Society 1936, pp. $373-84$.

45 K. Connelly, 'A Yarrow Lawn', Pacific Horticulture., 52(3) (1991), 28-30.

46 Anon, 'The Yarrow Lawn', San Marcos Growers, (2009) <http://www.smgrowers.com/gardens/yarrow.asp $>$.

47 Carolyn. Singer, Deer in My Garden, Volume 2: Groundcovers \& Edgers (Santa Rosa, California: Garden Wisdom Press, 2008).

48 Anon, 'Lawn Alternatives.', (Santa Barbara: City of Santa Barbara Water Conservation Program, 2008).

49 Hugh. J. Prichard, 'Selfheal Lawn', (Personal Communication: Prichard, 2010).

50 Margery. Fish, Ground Cover Plants. (London: B. T. Batsford, 1964).

51 R.D.C. Evans, Bowling Greens. Their History, Construction and Maintenance. (Bingley: The Sports Turf Research Institute, 1988).

52 Anon, 'The Caledonian Bowls Club.', Sportsground.co.nz, (2012) $<$ http://www.sportsground.co.nz/files/Site/323/7/Pdf/100602164334HHXNYUAL.pdf $>$. 
53 Caledonian Bowling Club. Dunedin. NZ., 'Our Opening Day 1938. Miss A.A. Greenslade Patroness Throwing the First Kitty of the Season.', Hocken Collections, Uare Taoka o Hakena, University of Otago, Caledonian Bowling Club, MS-3390/018. .

54 David. Ormsby, 'Understanding Cotula Maniototo Plants', Pitchcare, (2009) <http://www.pitchcare.com.au/magazine/understanding-cotula-maniototoplants.html>2013].

55 F. Herbert. Borman, Diana. Balmori, and T. Gordon. Geballe, Redesigning the American Lawn. A Search for Environmental Harmony. 2nd edn (New Haven \& London: Yale University Press, 2001).

56 J. Koh, 'An Ecological Aesthetic', Landscape Journal, 7 (1988), 177-91.

57 Loren. B. Byrne, 'Of Looks, Laws and Lawns: How Human Aesthetic Preferences Influence Landscape Management, Public Policies and Urban Ecosystems.', in Emerging Issues Along Urban-Rural Interfaces: Linking Science and Society., ed. by D. Laband (Auburn University, Auburn, AL., 2005), pp. 42-46.

58 Joan. Iverson Nassauer, 'Messy Ecosystems, Orderly Frames', Landscape Journal, 14 (1995), 161-70.

59 Nigel. Dunnet, and James. Hitchmough, The Dynamic Landscape. Design, Ecology and Management of Naturalistic Urban Planting. ed. by Nigel. Dunnet and James. Hitchmough (London \& New York: Taylor \& Francis, 2004).

60 V.A. Gibeault, and V.B. Youngner, 'Strawberry Clover with Bermudagrass for Low Maintenance Turf.', (Sacramento: University of California. Division of Agricultural and Natural Resources, Sacramento., 1983 -1986).

61 M.H. Meyer, \& Pederson, B., 'Low Maintenance Alternative Turf Trials', Journal of Turfgrass Management, 3 (1999), 49-57.

62 Thomas.W. Cook, 'Low Maintenance Turf', Hardy Plant Society of Oregon, 9(1) (1993), 9-15. 
63 - - , 'Low Maintenance Alternatives to Conventional Grass Lawns: Ecolawns Revisited', (OSU: Oregon State University, 2005).

64 W. Rumball, 'Breeding Progress Towards Wildflower Lawns', in The 6th International Turfgrass Research Conference. , ed. by International Turfgrass Society. (Tokyo: Japanese Society of Turfgrass Science., 1989), pp. 91-93.

65 Rosemary. Castle, Liberating Lawns (Gloucestershire.: Alternatives., 2001).

66 D Given, and I Spellerberg, eds., Going Native: Makin Use of New Zealand Plants (Christchurch: Canterbury University Press, 2004).

67 Jonah. H. Peretti, 'Nativism and Nature:Rethinking Biological Invasions.', in Bioinvaders., ed. by Sarah. Johnson (Cambridge: White Horse Press, 2010). 


\section{List of figures:}

Figure 1. European Climatic Zones.

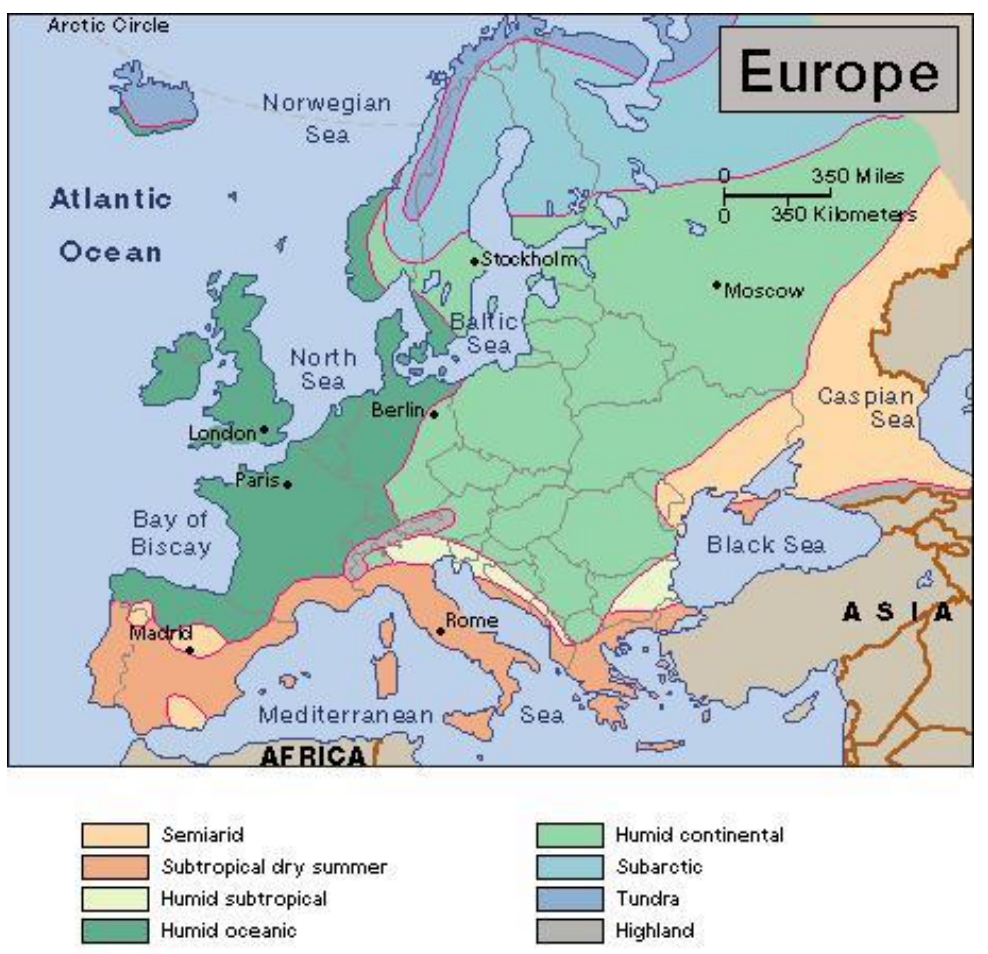

Figure 2. An Alpine Lawn. Hochobir Mountain, Slovenia. Courtesy: Kaye Griffiths, (2006)

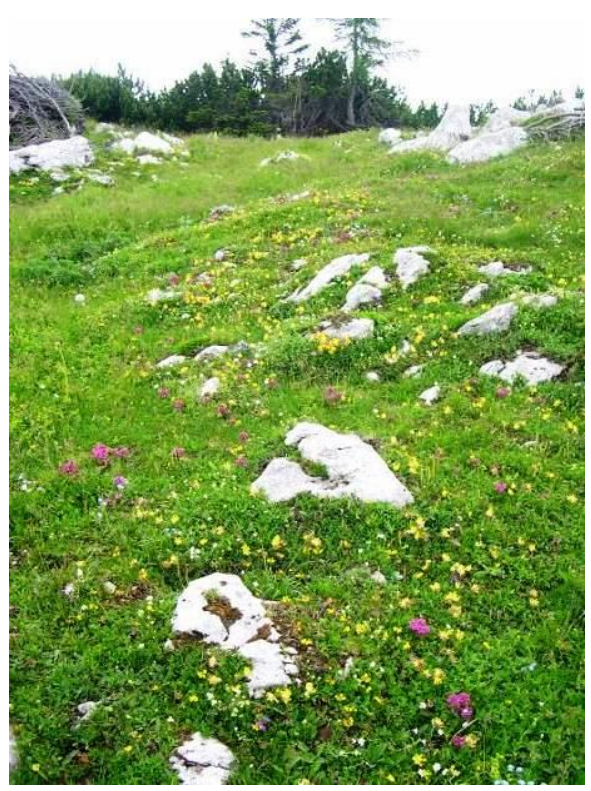


Figure 3. The Yarrow Lawn at San Marco Growers. Courtesy: San Marcos Growers (1991)

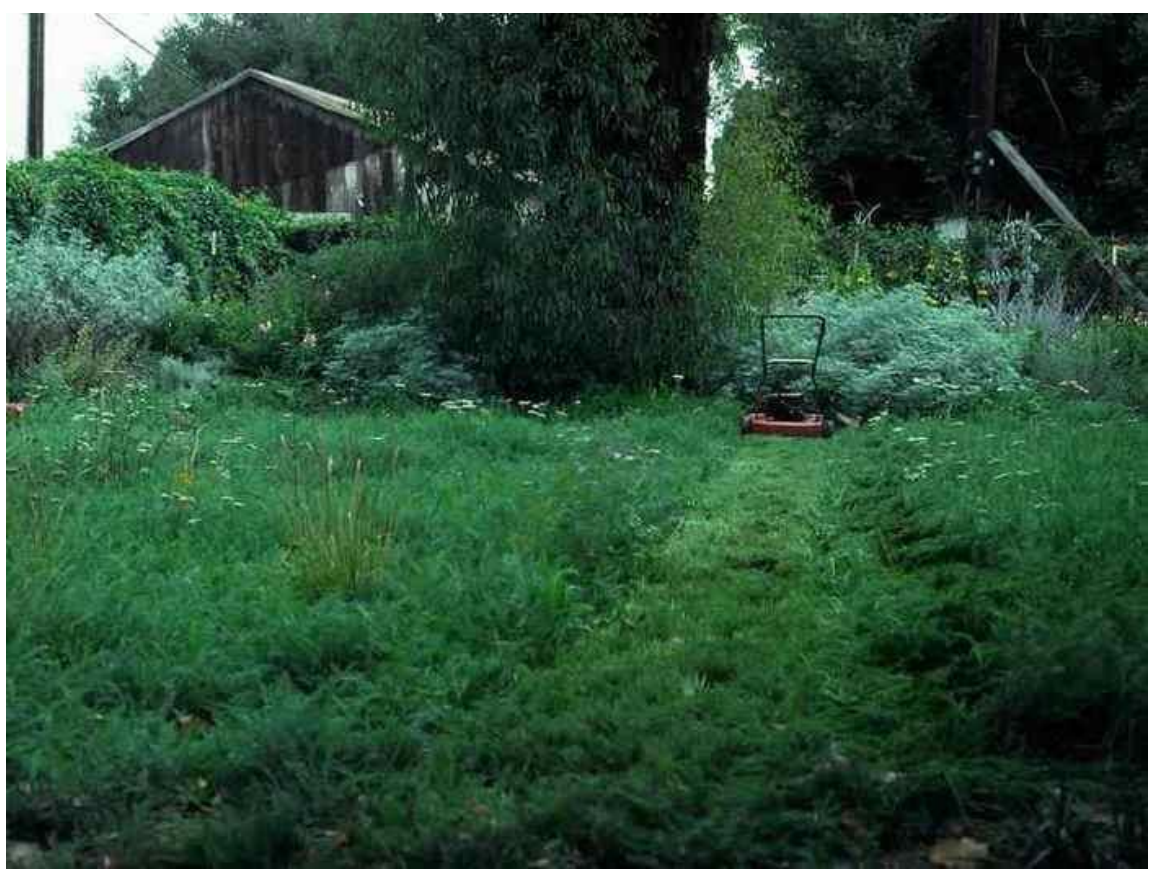

Figure 4. Selfheal lawn in spring. Courtesy: Hugh J Prichard (2010)

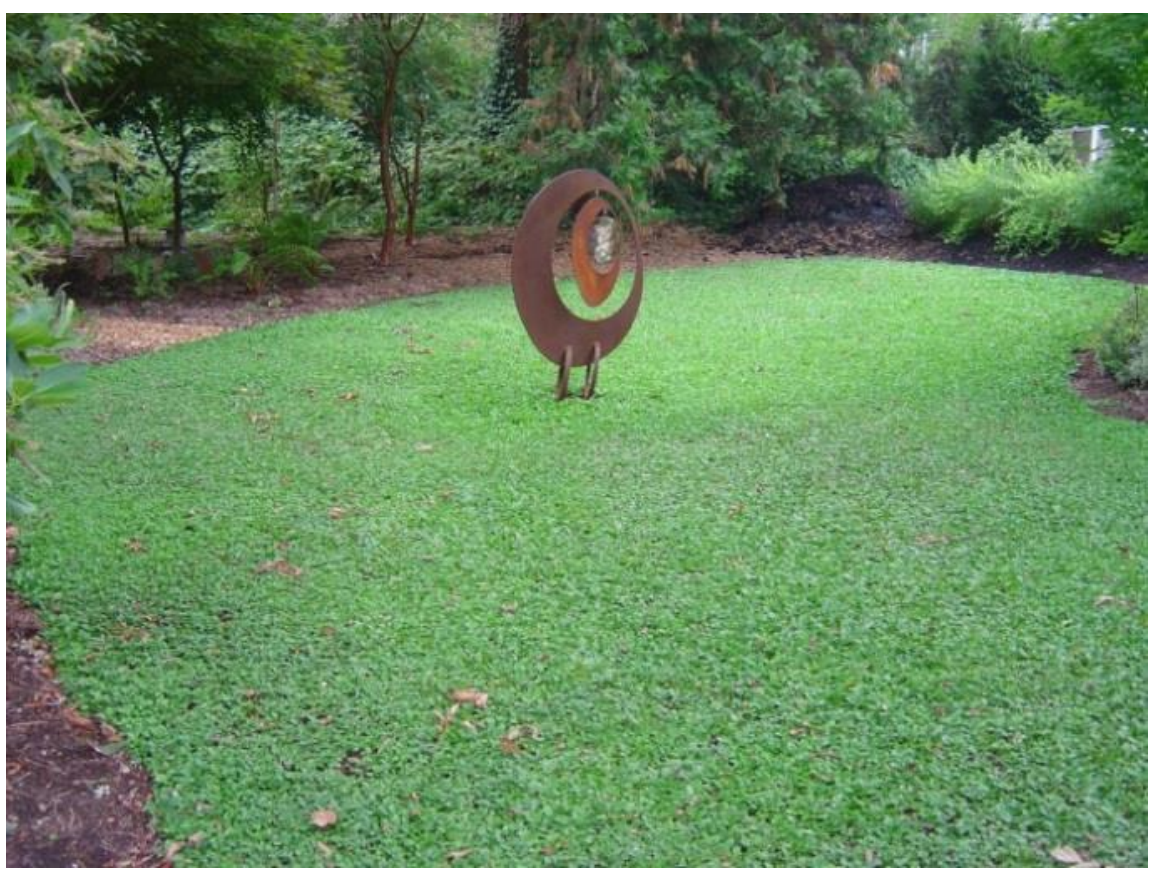


Figure 5. Selfheal lawn in summer. Courtesy: Hugh J Prichard (2010)

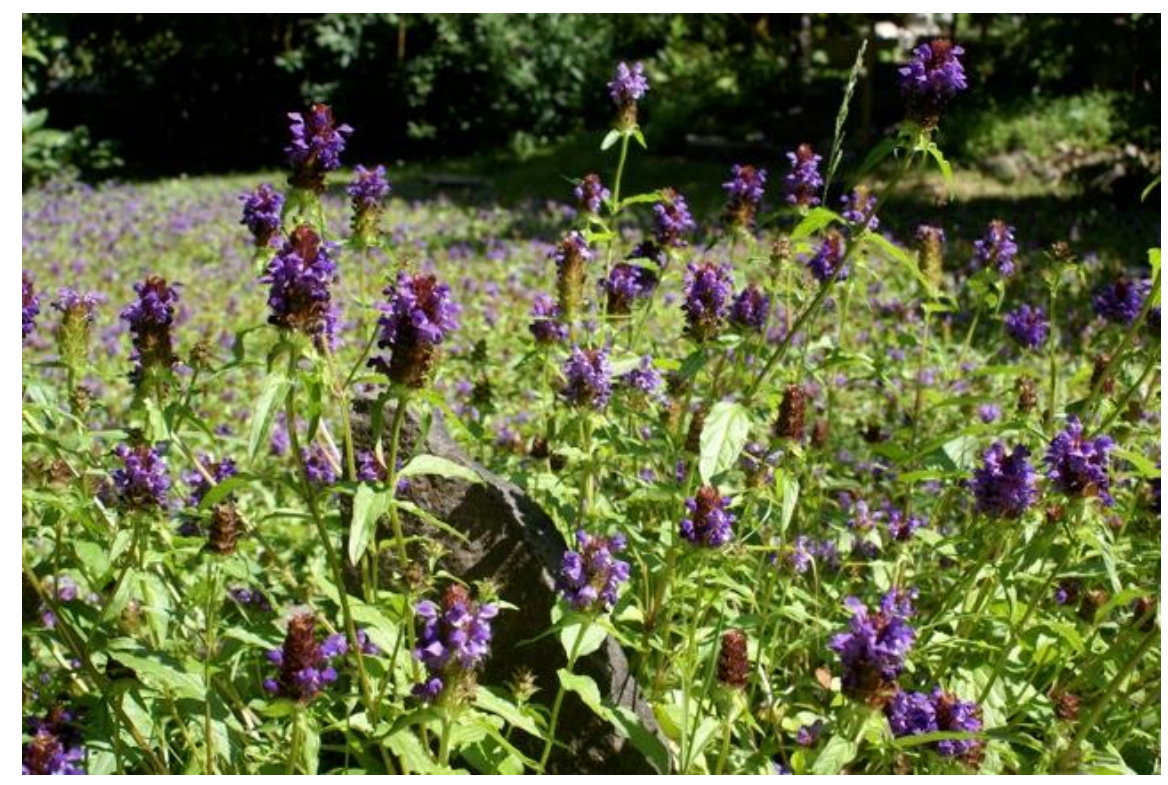

Figure 6. The Leptinella dioica bowling lawn at the Caledonian Bowling Club, Dunedin, NZ (1938). Courtesy: Hoken Library, University of Otago, NZ. ${ }^{53}$

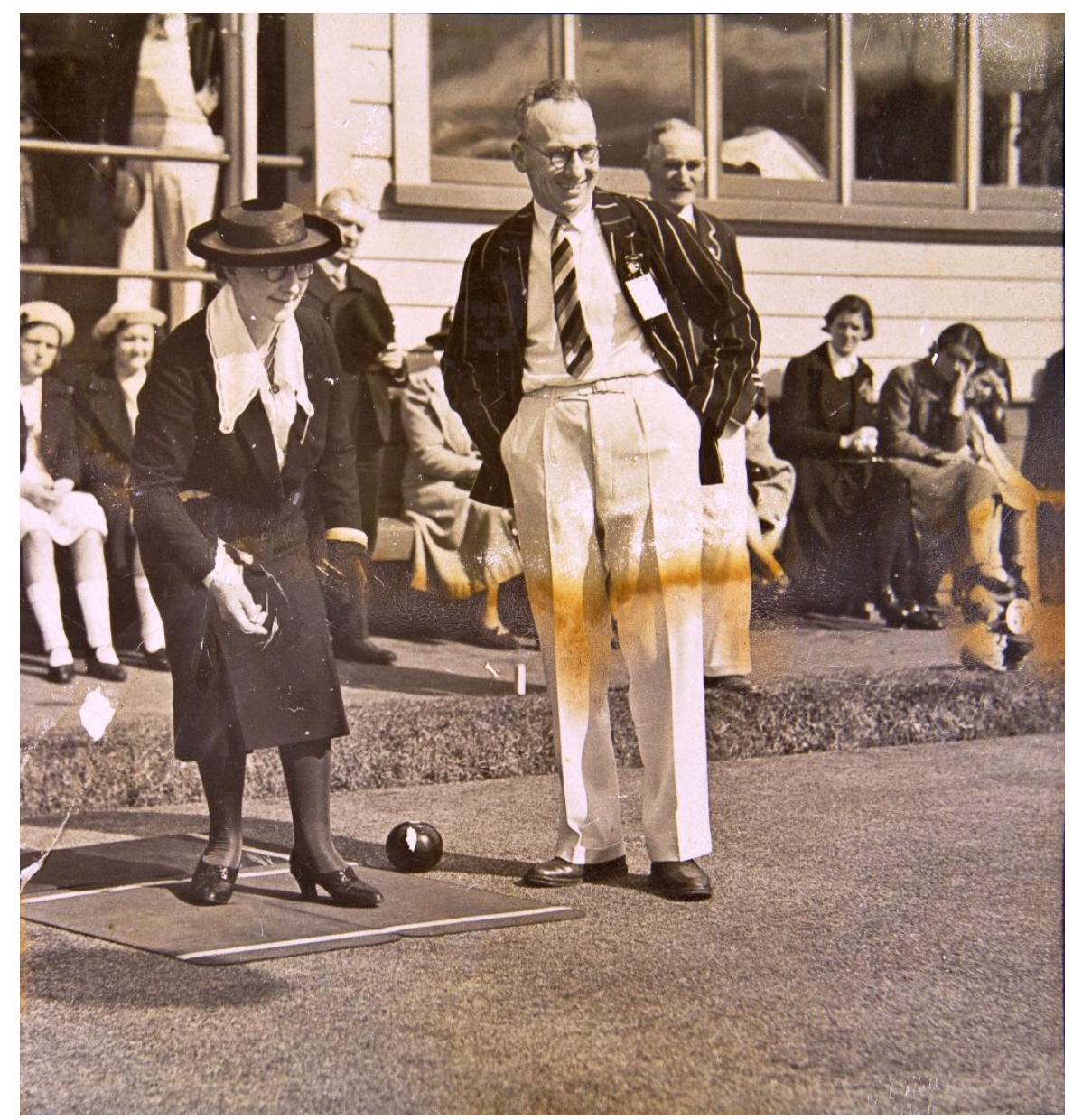


Figure 7. Grass-free lawn in spring. Courtesy: Lionel Smith (2011)

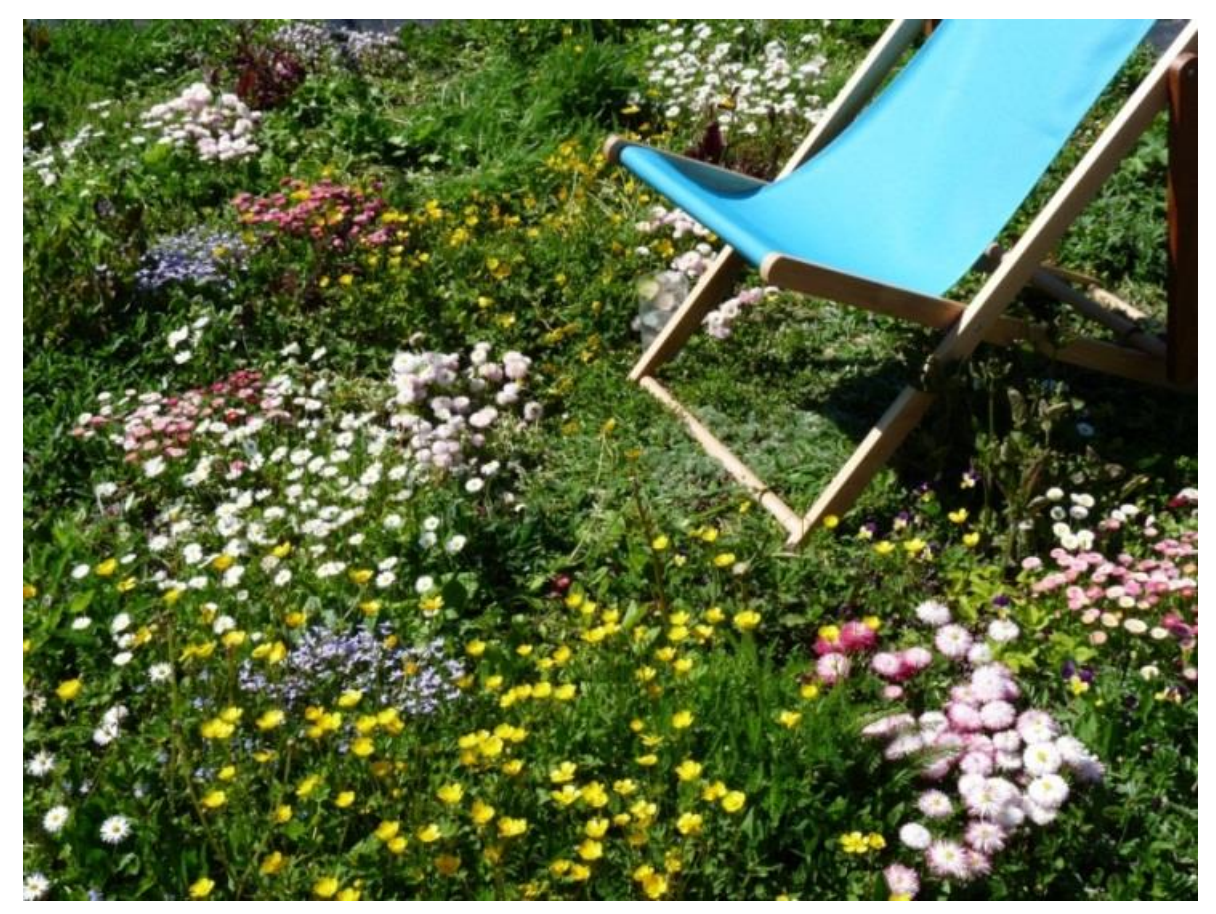

